\title{
Feminist approaches to sexuality and law scholarship
}

Article

Accepted Version

Auchmuty, R. (2015) Feminist approaches to sexuality and law scholarship. Legal Information Management, 15 (1). pp. 4-7. ISSN 1472-6696 doi:

https://doi.org/10.1017/S1472669615000055 Available at https://centaur.reading.ac.uk/39421/

It is advisable to refer to the publisher's version if you intend to cite from the work. See Guidance on citing.

To link to this article DOI: http://dx.doi.org/10.1017/S1472669615000055

Publisher: Cambridge University Press

All outputs in CentAUR are protected by Intellectual Property Rights law, including copyright law. Copyright and IPR is retained by the creators or other copyright holders. Terms and conditions for use of this material are defined in the End User Agreement.

\section{www.reading.ac.uk/centaur}

\section{CentAUR}

Central Archive at the University of Reading

Reading's research outputs online 


\title{
FEMINIST APPROACHES TO SEXUALITY AND LAW SCHOLARSHIP
}

\section{Rosemary Auchmuty}

School of Law

University of Reading

Foxhill House

Whiteknights Road

Reading RG6 7BA

\begin{abstract}
Sexuality and Law scholarship is a new and developing field but, like most legal scholarship, it is dominated by masculine concerns and methodologies. This article explains why research that ignores feminist concerns and methodologies will be incomplete and inaccurate, and suggests questions that should be asked of resources to ensure a complete and accurate coverage of the topic.
\end{abstract}

\section{Biography}

Rosemary Auchmuty is Professor of Law at the University of Reading. She writes on gender and sexuality issues, property law, legal history and girls' fiction.

\section{Word count}

2800 words 


\section{FEMINIST APPROACHES TO SEXUALITY AND LAW SCHOLARSHIP \\ Rosemary Auchmuty}

The workshop at which this paper was presented was directed at doctoral and early career scholars in law. My aim was to show how mainstream Sexuality and Law scholarship is dominated by masculine concerns and methodologies and to suggest how, using feminist approaches, scholarship might be more accurate and inclusive. Feminism is a broad church, embracing many theoretical strands. I would emphasise, however, that employing a feminist approach is not simply a choice of position among many others; it is an essential element in good scholarship. Without the feminist considerations I am about to outline, the end product of the research will simply be incomplete. ${ }^{1}$

\section{Beyond theory}

A feminist approach is one that foregrounds gender. Indeed, "feminist" is the adjective that is applied to scholarship about gender; gender would not have become an issue for scholarship or law if it had not been brought to their attention by feminists. Feminist approaches remind us that the world is not composed solely of men; that women have different experiences from men; that the sexes exist in relation to each other, and that this is a relationship not simply of inequality but often of overt discrimination and oppression. The fact that there were no women in the UK legal professions until 1920, for example, was not because no woman wanted to practise as a lawyer before that date; it was because men used every possible means, legal and extra-legal, to keep them out (Auchmuty 2011).

Feminist scholarship developed from second wave of feminism in the 1970s. This is not to say that feminist critiques did not exist before then, rather that they were not regarded as serious research until feminists entered the academy in substantial numbers in the 1980s. Feminism came late to law and, while now an accepted and growing field, it remains separate and marginal; it is still possible for law students to meet no feminist input throughout their entire degree programme. Only this week I was shown a new textbook on Jurisprudence that gave no attention to either women or feminist jurisprudence in its entire 120,000 word length. ${ }^{2}$ The publisher seemed surprised when I expressed concern; while fully aware that women make up more than half our law students (and the market for his books), he had simply not noticed there was nothing in this book that applied specifically to women. ${ }^{3}$

Sexuality scholarship has developed over the same period through two quite separate theoretical strands, themselves gendered. Gay liberation emerged after the legalisation of gay male sex in 1967. But its focus on male concerns, such as the unequal 
age of consent and restrictions on public sex, and its disregard for women's concerns, such as custody of children, led to many women shifting their allegiance to the women's movement in the early 1970s. Lesbian feminism introduced sexuality into a movement hitherto perceived to represent only heterosexual women and socialist issues (Auchmuty 2000: 783). More recently, feminists in the academy have found allies among queer theorists, many of them men sympathetic to women's concerns (e.g. Stychin 1995). But large sections of the gay male population have remained untouched by feminism, so that much sexuality scholarship produced by men continues to ignore gender, while still using the universalist tone that purports to speak for everyone. ${ }^{4}$

\section{Beyond the male}

The classic problem that pervades all knowledge and all scholarship, such as the Jurisprudence text I mentioned above, is the simple absence of women in mainstream work; the use of universal words to describe the experience of one sex only; the continuing acceptability of accounts that focus solely on male concerns. When people hear or use the words "gay" and "homosexual", it is men they see in their mind's eye, men whose experiences they imagine or describe. The consequence is not simply that lesbians become invisible, they become implicated in male gay practices (both sexual and social) which actually they are much less likely, and heterosexual men much more likely, to engage in. Women form a tiny proportion of sexual abusers, lesbians even fewer, but that did not stop the courts from denying lesbian mothers custody of their own children for decades. During the AIDS crisis, when lesbians (the least vulnerable group) rallied round to attack the culture of gay-bashing and help care for their ill gay friends, their own concerns were moved off the gay agenda as unimportant in the face of this lifechanging epidemic.

What is clear then is that lesbians are often situated in a very different place from gay men, just as heterosexual women are situated differently from heterosexual men. It is not an essential difference; indeed, a central feature of feminism is that gender is socially constructed, and our goal is the abolition of gender, that is, the creation of a world in which one's biological sex makes no social difference. But, as long as gender does make a difference, the first question the scholar of sexuality and law must ask of her sources is: Is the situation different for men and for women? Does this law apply equally and in the same way to men and women? Who campaigned for it, and why? Who benefits? (Auchmuty 1997).

Answering these questions usually gives the lie to any assumption of identity of interests among lesbians and gay men. Some examples: consensual sex between adult 
men in private was illegal between 1885 and 1967. So in one sense lesbians, who were outside this law, were less vulnerable to legal intervention and the danger of harassment, humiliation and blackmail. But that is not to say that lesbians were unaffected: on the one hand, their absence from legal recognition rendered them silent and invisible for decades, yet, when prosecuted under other provisions such as sexual assault, they were subjected to excessive penalties, as is usually the case with female offenders (Derry 2007). It is this last part that is usually ignored in accounts of Sexuality and Law, which may be unclear about whether "sodomy" laws actually applied to women as well as men or, alternatively, may assume that lesbians lived easy lives untouched by legal and social opprobrium.

Even today, with criminalisation behind us, lesbians and gay men experience the law differently. Take the Civil Partnership Act 2004, which allows same-sex couples to register their partnership and acquire more or less the same rights and responsibilities as heterosexual married couples. ${ }^{5}$ Largely campaigned for by men, often for financial reasons (inheritance tax featured prominently in the publicity), the civil partnership has proved less attractive for women - often, again, for financial reasons. Men are more likely to have property they want to protect and pass on through inheritance and pensions. Women are likely to be poorer, so these provisions are of no practical use to the majority, and may indeed be detrimental, as where benefits are calculated on a household basis. ${ }^{6}$ This law treats lesbians and gays equally, but lesbians as a group do not benefit from it in the same way as men as a group.

So, the first principle is to "ask the woman question", and do not assume an identity of interests between lesbians and gay men. The truth is that lesbians have more in common with heterosexual women than with gay men, simply because of the gendered differences and inequalities that still dominate society. That means, for library work, that searches should be made under "lesbian" as well as "gay" and "homosexual"; that work by women as well as men should be consulted; and that where the scholar finds that only the male experience appears to be described, this should be noted and problematised.

\section{Beyond the middle-class, white, coupled male}

The person envisaged in much of the recent civil partnership/same-sex marriage literature is the worthy male citizen, the employed or retired man long settled with a partner in a home they own. He thinks it's unfair he can't get married like his heterosexual friends. He thinks it's unfair that if he or his partner dies, inheritance tax will be payable on his estate because their house is now worth three-quarters of a million 
pounds. He thinks it's unfair that his life insurance policy costs more than a heterosexual man's because gay men are associated with a higher risk of sexually transmitted disease. So he campaigns for law reform, and he gets it: and now (mark my words) he will be focusing on gay men's access to reproductive rights. But, as Neil Cobb has written in an excellent article on this issue, the removal of the sexually transmitted disease presumption in insurance policies for gay men does nothing for those of African origin travelling to Africa who will still pay more because they, too, are presumed to be at greater risk of HIV/AIDS (Cobb 2010). Likewise, civil partnerships and same-sex marriage, with their legal and social privileges, do nothing for uncoupled gays and lesbians, and single people generally. And I predict that access to reproductive rights will be claimed by many gay men without thought for the exploitation of commercial surrogate mothers in third-world countries. ${ }^{7}$

It is important, then, to consider the situation of all gays and lesbians, and all people generally, not simply the relatively privileged campaigners for yet more privileges, who often seem to disregard those excluded from those privileges or actually made more vulnerable by the dominant group's new access to "rights". The gay rights literature is dominated by this narrow, self-interested kind of scholarship. Seeking out specifically feminist accounts, especially those that foreground class, is essential. ${ }^{8}$

\section{Beyond rights}

Notwithstanding their differences, the theoretical underpinnings of women's liberation and gay liberation in the 1970s had one thing in common: an analysis of power. The incorporation of the European Convention on Human Rights into domestic law in 1998 led to a new legal consciousness conceived in terms of rights, leading in turn to the dominant discourse today of equality and diversity. Thus the old political basis of both Gender and Sexuality and Law scholarship, which focused on the ways that dominant groups (heterosexuals, men) oppress subordinate groups (homosexuals, women), gave way to a liberal call for inclusion for some, but not all, individuals and groups. A rights analysis of necessity categorises people into identity groups and, where women were once seen as a separate identity group from men, when sexuality became the defining characteristic gays and lesbians were grouped together and the gendered differences simply disappeared from attention. These days, where people once spoke of the "lesbian and gay" community (Auchmuty, Jeffreys and Miller 1992), we see "LGBT" (lesbian, gay, bisexual and transgender) and recently I saw "LGBTQI" (lesbian, gay, bisexual, transgender, queer and intersex) all lumped together as one "community". In truth, of course, each of these groups has separate and sometimes conflicting interests. That is 
not to say that lesbians might not sometimes choose to ally themselves politically with gay men, as they did in the campaign against section 28 of the Local Government Act 1988 which prohibited the "promotion" of homosexuality by schools and local authorities. But what generally happens when women work together with men is that the men's voices dominate and their interests prevail. In the anti-section 28 campaign, gay men argued that homosexuality could not be promoted, since homosexuals were born, not made. The lesbian feminist analysis - that sexuality is socially constructed, not inborn - was drowned out, even though it reflected many women's personal experience of moving from a heterosexual to a lesbian identity. For these reasons, then, researchers should avoid the mindless conflation of lesbian, gay, transgender and the rest; they should be precise about who exactly is encompassed in any discussion and, where necessary, include the separate and different experiences and analyses of all groups.

\section{Beyond equality}

Current debates in Sexuality and Law are almost always conceptualised in terms of equality. There is nothing wrong with equality, but it misses the point for feminism, whose goal is not simply to be included in the status quo, but to transform it. Historically, women have not simply been unequal to men, they have been oppressed by them and the institutions of patriarchy constructed to perpetuate male power. Gays and lesbians, similarly, have not just been unequal to heterosexuals; they have been oppressed by them and the institutions of heterosexism and homophobia constructed to perpetuate the heteropatriarchy.

Equality has never been women's first priority. First-wave feminists in nineteenth-century Britain were not simply campaigning for equal rights to education, work, property, the vote, as they have far too often been characterised; they were fighting to remove the oppressive and unjust laws that gave men power to dominate, exploit and exclude them and to control their property and their bodies. In other words, women needed to get men off their backs before they could even think of working towards equality (Auchmuty 2008). Likewise, for all the gays and lesbians who have been able to come out and be fully accepted at home and at work and even to get married as a result of the huge liberal shifts in mainstream society in the late twentieth and early twentyfirst centuries, there are many others who still suffer not simply generalised inequality but ideological and familial pressures, social ostracism, violence and even death for their sexual choices.

So a Sexuality and Law analysis that stops short at rights and equality is an incomplete one. First, in pressing for equality, we need to consider whether we really 
want equality with dominant groups who for centuries have perpetuated their own power through oppressive practices such as those we now abhor in other parts of the world or "other" communities at home. Second, we need to think about changing the world: challenging heterosexual power, shifting behaviour and attitudes and, as many feminists have argued, making heterosexuals more like us - more egalitarian, less gendered in their relationships, more inclusive in their communities.

\section{Beyond law}

Feminists are cautious about looking to law to tackle injustice. The expectation that a change in the law will solve our difficulties is naïve and has proved disappointing for women time and time again. Today, for example, we have very severe rape laws, but we still have a high rate of rape and a low rate of convictions. Dominant structures have a way of negotiating legal barriers, reconfiguring debates and finding a way to return to the preferred status quo or something close.

What we need, much more than legal change, is attitudinal change; and, while the two are clearly linked - the change in public opinion towards gays and lesbians was in large part driven by the Civil Partnership Act 2004 - it is education that is the key to our liberation. The more people know about law and sexuality and the more that rational argument is available to counter prejudice and religious dogma, the more individuals will be empowered to take control of their own lives and make sensible decisions without needing to look to law's partial and inadequate protection.

Alongside education, we need to think in terms of politics. Feminism is both an intellectual analysis and a politics, and Sexuality and Law scholars need to locate their research in the context of a rapidly changing society in which long-held values of compassion and solidarity are being removed one by one, to be replaced by ideologydriven policies without evidential basis, whose goal will surely be, intentionally or not, the erosion of the equality and diversity we have worked so hard to achieve. As Homa Khaleeli wrote in the Guardian on 28 October 2014, "Feminism is not just about wishing for women to have the same rights and opportunities as men: it is a movement created to ensure that it happens." Sexuality and Law scholarship must go beyond the "me-too" equal-rights agenda to see connections and make alliances with other social movements and return to political struggle, not simply legal reform, to get the world we want. For legal researchers, this means looking beyond the law shelves in the library to search the sociology, social history, political science and literature offerings for information about political movements, especially feminism, that have led and will lead to legal change. 


\footnotetext{
${ }^{1}$ Feminist work in Sexuality and Law can be found scattered across most socio-legal journals, especially Feminist Legal Studies, and in edited collections such as Munro and Stychin 2007.

${ }^{2}$ I will not shame it by naming the book or its publisher.

${ }^{3}$ For a small sample of feminist jurisprudence collections, just to show that this is not a new area, see Barnett 1996, Barnett 1998, Bowman et al 2010, Dowd and Jacobs 2006, Fineman et al 2009, Levit and Verchik 2006, Olsen 1995, Richardson and Sandland 2000, Smith 1993.

${ }^{4}$ Much of the literature civil partnership and same-sex marriage falls into this category.

${ }^{5}$ The Marriage (Same Sex Couples) Act 2013 confers the same rights as civil partnership.

${ }^{6}$ Prior to 2005 same-sex couples were treated as two individuals (thus attracting higher benefits) because their relationship was not recognised in law. See Auchmuty 2007.

${ }^{7}$ At the very workshop at which I presented this paper, a young male doctoral student asked me what the problem was for the women surrogates from third-world countries: 'Isn't it just a contract?', he said. Rights did not come into it, nor the risks of pregnancy and childbirth, nor even the unequal bargaining power of the respective parties.

${ }^{8}$ For example, there are dozens of books by men (mostly American) on same-sex marriage, all presenting the same liberal arguments. Researchers on this topic should be directed to Barker 2012 for a feminist view.
}

\section{References}

Auchmuty, R., Jeffreys, S. and Miller, E. (1992) “Lesbian History and Gay Studies: Keeping a feminist perspective” Women's History Review 1, 89-108

Auchmuty, R. (1997) “Lesbian Law, Lesbian Legal Theory” in S. Andermahr and G. Griffin (eds) Straight Studies Modified. London, Cassell

Auchmuty, R. (2000) “United Kingdom”, in B. Zimmerman (ed) Lesbian Histories and Cultures: An Encyclopedia. New York, Garland, 781-785

Auchmuty, R. (2007) "Out of the Shadows: Feminist silence and liberal law" in C. Stychin and V. Munro (eds) Sexuality and the Law: Feminist Engagements. London, Routledge

Auchmuty, R. (2008) “The Married Women’s Property Acts: Equality was not the issue” in R. Hunter (ed) Rethinking Equality Projects in Law: Feminist Challenges. Oxford, Hart Publishing

Auchmuty, R. (2011) “Whatever happened to Miss Bebb? Bebb v The Law Society and women's legal history" Legal Studies 31, 199-230

Barker, N. (2012) Not the Marrying Kind: A feminist critique of same-sex marriage. Basingstoke, Palgrave Macmillan

Barnett, H. (1996) Sourcebook on Feminist Jurisprudence. London, Cavendish

Barnett, H. (1998) Introduction to Feminist Jurisprudence. London, Cavendish

Bowman, C.G., Rosenbury, L.A. and Tuerkheimer, D. (eds) (2010) Feminist Jurisprudence, Cases and Materials. $4^{\text {th }}$ ed. St Paul, West Academic Publishing

Cobb, N. (2010) "Queer[ed] risks: Life insurance, HIV/AIDS, and the gay question" Journal of Law and Society $37,620-50$

Derry, C. (2007) “'A sort of juridical phantasm': the criminal law's (lack of) engagement with lesbianism". Unpublished $\mathrm{PhD}$ thesis, University of Westminster

Dowd, N.E. and Jacobs, M.S. (eds) (2006) Feminist Legal Theory: An Anti-Essentialist Reader. New York University Press 
Fineman, M.A., Jackson, J.E. and Romero, A.P. (eds) Feminist and Queer Legal Theory (2009) Farnham, Ashgate

Levit, N. and Verchik, R.R.M. (2006) Feminist Legal Theory: A Primer. New York University Press

Munro, V. and Stychin, S. (eds) (2007) Sexuality and the Law: Feminist Engagements. London, Glasshouse Press

Olsen, F. (ed) (1995) Feminist Legal Theory. Aldershot, Dartmouth, 2 vols

Richardson, J. and Sandland, R. (eds) (2000) Feminist Perspectives on Law and Theory. London, Cavendish

Smith, P. (ed) (1993) Feminist Jurisprudence. New York, Oxford University Press

Stychin, C. (1995) Law's Desire: Sexuality and the Limits of Justice. London, Routledge 